\begin{tabular}{lr}
\hline PRACE NAUKOWE UNIWERSYTETU EKONOMICZNEGO WE WROCŁAWIU \\
RESEARCH PAPERS OF WROCŁAW UNIVERSITY OF ECONOMICS & \begin{tabular}{rr}
$\mathbf{n r}$ 473 • 2017 \\
\hline Gospodarka turystyczna w regionie.
\end{tabular} \\
Przedsiębiorstwo. Samorzą. Współpraca & $\begin{array}{l}\text { ISSN 1899-3192 } \\
\text { e-ISSN 2392-0041 }\end{array}$
\end{tabular}

\title{
Beata Rosicka
}

Uniwersytet Ekonomiczny we Wrocławiu

e-mail: rosickabeata@op.pl

\section{FUNKCJA TURYSTYCZNA ZAMKU KSIĄŻ}

\section{TOURIST FUNCTION OF KSIĄŻ CASTLE}

DOI: $10.15611 /$ pn.2017.473.43

JEL Classification: L83

\begin{abstract}
Streszczenie: Artykuł koncentruje się na zachowanym dziedzictwie kulturowym - zamku Książ w Wałbrzychu, trzecim co do wielkości zamku w Polsce, który od 2007 r. jest zwiedzany przez ponad 200000 turystów rocznie. Obiekt ten na trwałe wpisał się na listę najważniejszych atrakcji tworzących ofertę turystyczną Dolnego Śląska. Celem artykułu jest ukazanie zarysu dziejów Książa, jego wykorzystania turystycznego od 1945 do 2016 r., ze wskazaniem różnorodnych form turystyki, w ramach których obiekt ten stanowi cel wypraw turystów. W ostatniej części artykułu została przeprowadzona analiza ruchu turystycznego w zamku Książ w latach 2001-2016.
\end{abstract}

Słowa kluczowe: zamek Książ, funkcja turystyczna, atrakcje turystyczne, dziedzictwo kulturowe.

Summary: The article focuses on the preserved cultural heritage of Książ Castle in Wałbrzych the third largest castle in Poland, which is visited by more than 200000 tourists a year. The castle is on the list of the most important tourist attractions of Lower Silesia. The aim of the paper is to present the history of Książ Castle, its tourist use from 1945 to 2016, with the indication of various forms of tourism, within which the object is the target of trips of tourists. In the last part of the article the analysis of tourist traffic in the years 2001-2016 out was carried out.

Keywords: Książ Castle, tourist function, tourist attractions, cultural heritage.

\section{Wstęp}

Wśród zabytków architektury najważniejszymi atrakcjami turystycznymi ziemi wałbrzyskiej są bez wątpienia zamki. Ich budowę przypisuje się z księciu świdnicko-jaworskiemu Bolkowi I Surowemu, który intensywnie obwarowywał granice swego księstwa. Powstały wtenczas zamki Książ, Grodno, Cisy, Czarny Bór, Rogowiec, Radosno oraz Nowy Dwór [Kajzer i in. 2007]. Jednakże największym zamkiem na Dolnym Śląsku, a zarazem trzecim co do wielkości w Polsce, jest Książ usytuowany na północnym krańcu miasta Wałbrzycha, na terenie Książańskiego Parku Kraj- 
obrazowego, nazywany niegdyś „,perłą Śląska”. W 1509 r. zamek został oddany arystokratycznemu rodowi Hochbergów, który po otrzymaniu rezydencji na własność w 1605 r., władał obiektem przez ponad 400 lat [Łuczyński 1993]. W swojej przedwojennej historii zamek został dwukrotnie przebudowany (na początku XVIII w. oraz w latach 1908-1923) [Klimek 2001, Łuczyński 1997, Kajzer i in. 2007]. W 1944 r. Książ został przejęty na kwaterę wojenną przez paramilitarną Organizację Todt, w wyniku czego część dawnej rezydencji została zniszczona, a jej wyposażenie wywieziono. W tym czasie pod zamkiem, na dwóch poziomach (15 i $50 \mathrm{~m}$ ), przez więźniów z obozu koncentracyjnego Gross-Rosen w Rogoźnicy drążone były tunele w ramach budowanego w Górach Sowich kompleksu „Riese” [Kruszyński 2008]. 8 maja 1945 r. Książ został zajęty przez Armię Czerwoną, która dokonała dalszej dewastacji obiektu, wywożąc m.in. część zbiorów z biblioteki. W latach 1956-1962 niszczejący Książ został zabezpieczony przez wojewódzkiego konserwatora zabytków, a w 1974 r. rozpoczęto prace renowacyjne [Łuczyński 2010].

Od 1991 r. zamkiem zarządza Spółka Zamek Książ w Wałbrzychu, której założycielem i właścicielem jest gmina Wałbrzych. Przedmiotem działania Spółki są w szczególności: ochrona zabytków, działalność kulturalno-turystyczna, hotelarska, muzealnicza, związana z organizacją targów i wystaw oraz wynajem nieruchomości na własny rachunek [Zamek Książ... 2014].

Celem opracowania jest ukazanie wykorzystania turystycznego Książa w latach 1946-2016, ze wskazaniem form turystyki, w ramach których obiekt ten stanowi cel wypraw turystów. W ostatniej części artykułu dokonano analizy ruchu turystycznego w zamku Książ w latach 2001-2016. Metodami zastosowanymi do osiągnięcia powyższego celu były: analiza literatury przedmiotu i statystyk udostępnionych przez Spółkę Zamek Książ w Wałbrzychu oraz wywiady przeprowadzone bezpośrednio z pracownikami obiektu.

\section{Analiza oferty turystycznej zamku Książ}

\subsection{Wykorzystanie turystyczne zamku Książ}

Książ stanowił atrakcję turystyczną już w latach 30. XX w., jednakże wybuch II wojny światowej wstrzymał ruch turystyczny. Po 1948 r. turyści byli oprowadzani po Książu przez dwóch opiekunów zamku, tzw. samozwańczych przewodników, Edwarda Wawrzyczkę i Jana Szczotkę. W 1956 r. obsługą ruchu turystycznego zajął się wałbrzyski Oddział Polskiego Towarzystwa Turystyczno-Krajoznawczego, którego głównym zadaniem było stworzenie profesjonalnej kadry przewodników. Do połowy lat 80 . trasa turystyczna prowadziła tylko przez tarasy zamkowe od baszty Prochowej na tarasie prochowym po taras południowy. W 1986 r. zarząd Koła Przewodników po Książu zatwierdził nową trasę turystyczną, obejmującą zarówno tarasy zamkowe, jak i część pierwszego piętra, m.in. z Winiarnią, Salą Konrada, Czarnym Dziedzińcem, Holem Modrzewiowym, oraz skrzydło barokowe. Zwiedzanie 
rozpoczynano przy baszcie Prochowej, a kończono przy baszcie Jerzego z wejściem na taras kasztanowcowy [Będkowska-Karmelita 2004]. W ciągu kilkudziesięciu lat, w wyniku postępujących prac konserwatorskich, trasy turystyczne po zamku uległy wielu zmianom. Od 2 kwietnia 2012 r. turyści mają do wyboru trzy trasy zwiedzania z przewodnikiem:

1. „Książ barokowy” - prowadzącą przez trakt barokowy. Czas zwiedzania wynosi ok. $30 \mathrm{~min}$.

2. „Od Piastów do tajemnic II wojny światowej” - obejmującą trasę „Książ Barokowy", a także pomieszczenia zamkowe przebudowane podczas II wojny światowej, Hol Myśliwski, kompleks Sali Balowej do Sali Konrada z Czarnym Dziedzińcem. W 2005 r. dla zwiedzających udostępniono część podziemnego tunelu z okresu II wojny światowej, o długości 96 m. Czas zwiedzania wynosi ok. 90 min.

3. „Szlakiem Daisy” - trasa poszerzona o zwiedzanie 14 tarasów zamkowych oraz części Książańskiego Parku Krajobrazowego z zabytkową aleją lipową pod kaplicę grobową Hochbergów i punktem widokowym na Książ. Czas zwiedzania wynosi ok. $140 \mathrm{~min}$.

Istnieje również możliwość zwiedzenia zamku indywidualnie, bez przewodnika, według tablic wyznaczających kierunek trasy. W zwiedzanych salach przygotowane zostały opisy w językach polskim, angielskim oraz niemieckim. Na zwiedzanie istnieje możliwość zakupienia biletów online. Od 19 października 2016 r. w ramach biletu na zwiedzanie zamku bez przewodnika udostępniono aplikację ,WOW Poland" - e-przewodnik dostępny na urządzenia mobilne. Przygotowano różne trasy tematyczne: „Dzieje zamku Książ”, „Z pamiętnika księżnej Daisy”, „Książańska opowieść dla Małych i Dużych” oraz wkrótce dostępną „Wojenne losy rezydencji Hochbergów". Przygotowana została także wersja dla głuchoniemych. Aplikacja będzie dostępna także w językach angielskim, niemieckim i czeskim. Od 16 października 2016 do 10 lutego 2017 r. aplikację pobrało 2400 osób.

Od lipca 2012 r. organizowane jest fabularyzowane nocne zwiedzanie trwające ok. 90 minut. Turyści zwiedzają komnaty zamkowe i nieudostępniane w trakcie dziennego zwiedzania m.in. dawne piwnice oraz kuchnie Hochbergów.

Poza organizacją ruchu turystycznego, od 2005 r. prowadzona jest działalność naukowa i dydaktyczna, tzw. lekcje zamkowe dla dzieci i młodzieży, m.in. „Baśniowy Książ”.

\subsection{Działalność muzealnicza zamku Książ}

W salach zamku Książ turyści mogą zapoznać się zarówno ze stałymi, jak i czasowymi wystawami muzealnymi. Od lipca 2013 r. na I piętrze można zobaczyć autorską ekspozycję Muzeum Gross-Rosen w Rogoźnicy „,Filie KL Gross-Rosen”, przybliżającą historię obozu koncentracyjnego oraz jego 99 filii. Od 8 stycznia 2014 r. na III piętrze zamku znajduje się m.in. wystawa stała „Sekrety z zamkowej szuflady” ukazująca historię Książa i jego mieszkańców, a od 28 kwietnia 2016 r. wystawa 
czasowa firmy zewnętrznej „Movie Heroes”, dodatkowo biletowana, prezentująca kostiumy z hollywoodzkich produkcji.

Od 11 lipca 2015 r. zbiory muzealne zostały wzbogacone eksponatami z Muzeum Narodowego we Wrocławiu: 38 obrazami oraz 2 rzeźbami, które zostały umiejscowione na traktach barokowym i środkowym, tworząc wystawę „Metamorfozy zamku Książ" [Lejman 2015]. W lipcu 2016 r. ekspozycja ta została wzbogacona o drugi co do wielkości obraz świecki na Dolnym Śląsku, „Alaryk w Rzymie”.

14 lutego 2017 r. w dawnych apartamentach księżnej Daisy została otwarta wystawa fotografii „Książ od kuchni” autorstwa Louisa Hardouina, nadwornego kucharza Hochbergów w latach 1909-1926. Wystawa została podzielona na trzy części: „Zamek, Ziemia, Zieleń, Zwierzęta”, „Hochbergowie i ich ród” oraz „Album rodzinny Hardouinów". Dodatkowo zwiedzający mogą skorzystać z sześciu stanowisk stereoskopowych pozwalających na obejrzenie zdjęć w trójwymiarze.

\subsection{Turystyka eventowa w zamku Książ}

$\mathrm{Na}$ terenie zespołu parkowo-pałacowego mają miejsce różnorodne cykliczne wydarzenia kulturalne, w tym organizowany od 34 lat majowy Festiwal Kwiatów i Sztuki. Stowarzyszenie Florystów Polskich tworzy w zamkowych salach kwiatowe aranżacje, natomiast odwiedzającym zostaje ukazany szeroki wybór kwiatów, krzewów, ceramiki oraz produktów regionalnych.

Od 2004 r. w Książu organizowany jest Międzynarodowy Festiwal Kameralistyki Ensemble im. Księżnej Daisy. Ideą festiwalu jest promowanie kameralistyki, zarówno w odniesieniu do utworów muzycznych, jak i dzieł teatralnych.

Od 2013 r. realizowany jest autorski projekt Joanny Lamparskiej, Dolnośląski Festiwal Tajemnic. Wydarzenie popularnonaukowe skierowane do miłośników historii zostało podzielone na wystawy, projekcje i wykłady oraz inscenizacje historyczne.

\subsection{Turystyka biznesowa w zamku Książ}

14 grudniu 2012 r. został sfinalizowany projekt „Przebudowa i modernizacja III piętra na cele wystawiennicze i konferencyjne - Centrum Kongresowo-Kulturalne Zamek Książ”. Inwestycja została zrealizowana w ramach działania 6.3 „Turystyka biznesowa” w Priorytecie VI „Wykorzystanie i promocja potencjału turystycznego i kulturowego Dolnego Śląska" Regionalnego Programu Operacyjnego dla województwa dolnośląskiego. Całkowita wartość projektu wyniosła 13430 673,57 zł, w tym dofinansowanie ze środków unijnych w kwocie $7 \mathrm{mln}$ zł. Na zaplecze konferencyjne obiektu składa się 11 sal o łącznej powierzchni $450 \mathrm{~m}^{2}$, w pełni wyposażonych w urządzenia multimedialne, które w sumie mogą pomieścić 400 osób [Zamek Książ... 2014]. 


\subsection{Działalność hotelarska}

W 2001 r. Spółka Zamek Książ w Wałbrzychu rozpoczęła działalność hotelarską. Trzygwiazdkowy hotel Książ, zlokalizowany w trzech oficynach zamkowych, dysponuje ponad 80 miejscami noclegowymi w 46 pokojach: 1-, 2-, 3-osobowych, suitach oraz apartamentach. Od stycznia 2014 r. goście hotelowi mają do dyspozycji pomieszczenia sportowo-rekreacyjne oraz pokój zabaw dla dzieci, zlokalizowane w baszcie budynku bramnego. Hotel oferuje turystom zakup m.in. voucherów podarunkowych oraz specjalnej oferty zaręczynowej [Zamek Książ... 2014].

Ponadto na terenie kompleksu zamkowo-parkowego znajdują się dwa inne hotele, dzierżawiące od Spółki Zamek Książ w Wałbrzychu budynki podzamcza.

\subsection{Palmiarnia w Lubiechowie i Stado Ogierów Książ jako przykłady turystyki przyrodniczej}

Palmiarnia w Lubiechowie, datowana na lata 1908-1911, powstała z inicjatywy ostatniego przedstawiciela rodu Hochbergów na zamku Książ, Jana Henryka XV. Centralną część stanowi 15-metrowy budynek z metalu i szkła, w którym zasadzono palmy daktylowe, a całość otoczono jednokondygnacyjnymi oranżeriami. Na dachu palmiarni utworzono galeryjkę widokową (obecnie kawiarnia). Wnętrze wyłożono tufem wulkanicznym sprowadzonym z Etny. Prócz palmiarni wzniesiono także cieplarnie, rosarium, ogrody w stylu japońskim oraz ogród owocowo-warzywny. Od 2012 r. palmiarnia jest częścią Spółki Zamek Książ w Wałbrzychu, a właścicielem jest gmina Wałbrzych, która przejęła obiekt od Agencji Rolnej Skarbu Państwa. Miłośnicy turystyki przyrodniczej mogą podziwiać ok. 250 gatunków roślin oraz jedyną w Polsce stałą wystawę bonsai. Bilet uprawniający do zwiedzania zarówno indywidualnego, jak i grupowego zamku obejmuje także zwiedzanie palmiarni [Zamek Książ... 2014].

W pobliżu zamku funkcjonuje Stado Ogierów Książ. Pierwotnie wzniesione w XVIII w. jako oficyny gospodarcze dla koni, w XIX w. zostało otoczone szkieletowymi zabudowaniami w kształcie czworoboków, natomiast na początku XX w. zaczęło pełnić funkcję stajni zamkowych. Zespół stadniny obejmuje 5 stajni, ujeżdżalnie oraz wozownie. W 1947 r. powstało Stado Ogierów Książ mające na celu odtworzenie ogierów typu śląskiego. Przy stadzie mieści się szkoła nauki jazdy konnej, a turyści mogą skorzystać m.in. z przejażdżek bryczkami [Leniartek 2015].

\section{Tendencja zmian natężenia ruchu turystycznego w zamku Książ w latach 2001-2016}

Na podstawie danych statystycznych zaprezentowanych w tabeli 1 można zaobserwować, iż w latach 2001-2016 zamek Książ odwiedziło łącznie 3551878 osób. Należy jednak wziąć pod uwagę fakt, iż jest to liczba turystów bez gości hotelu 


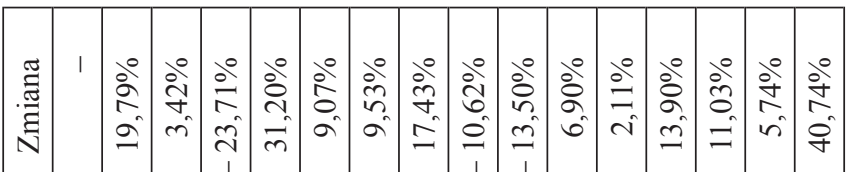

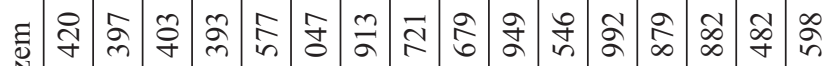

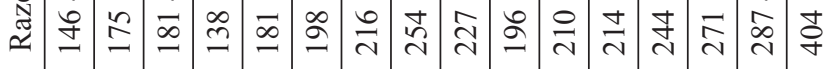

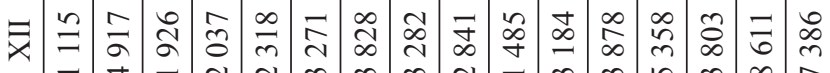

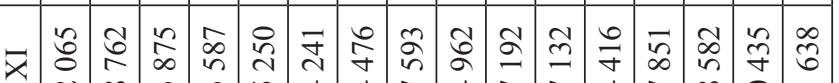

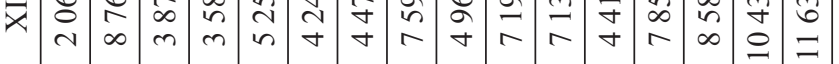

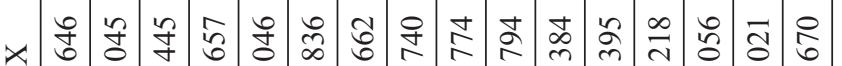

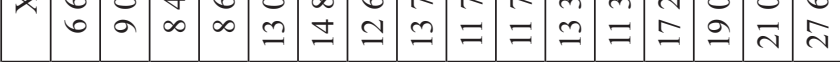

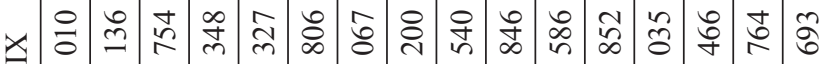

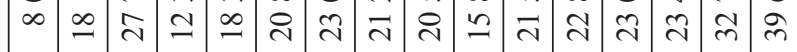

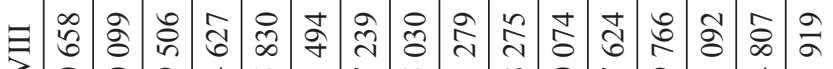

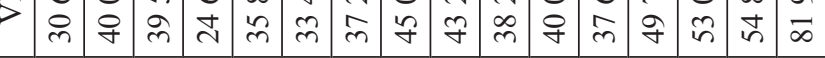

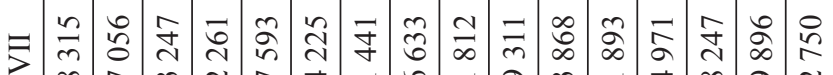

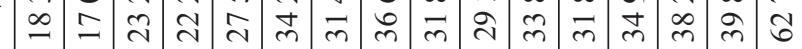

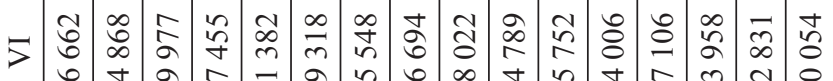

\&

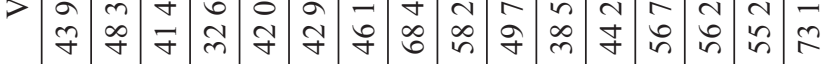

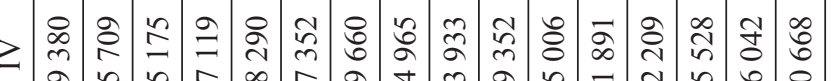

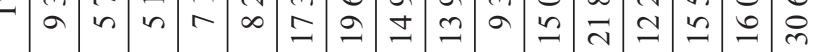

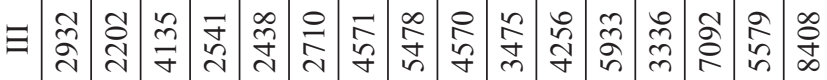

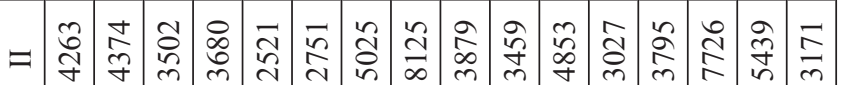

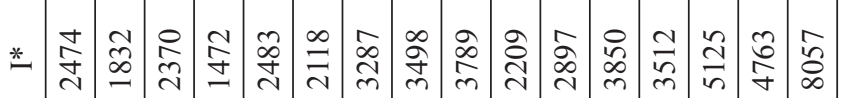

范 
Książ, którzy powyżej jednego noclegu mają możliwość zwiedzania indywidualnego zamku w cenie pokoju. Najmniejszą liczbę turystów odnotowano w 2004 r. 138393 osoby, był to spadek w stosunku do roku poprzedniego o 23,71\%. Najwięcej turystów zanotowano w 2016 r. - 404598 osób, był to wzrost w stosunku do roku 2015 o 40,74\%. Wpływ na tak wysoką liczbę odwiedzających miały m.in. załamanie sektora turystycznego na rynkach arabskich związane $\mathrm{z}$ atakami terrorystycznymi oraz nagłośnienie w sierpniu 2015 r. rzekomego odnalezienia miejsca ukrycia na 65. kilometrze linii kolejowej Wrocław-Wałbrzych pancernego pociągu z okresu II wojny światowej. Informacja ta przyciągnęła do Wałbrzycha nie tylko media ogólnopolskie, ale również zagraniczne, m.in. prasę brytyjską „The Telegraph” i ,The Guardian”, telewizję BBC i Sky news, niemiecki „Die Welt” oraz amerykańskie telewizje informacyjne CNN i Fox News [Rosicka 2016]. Zarząd Spółki, zachęcony wzrostem ruchu turystycznego, zamierza w 2017 r. udostępnić zwiedzającym całość podziemi wydrążonych pod obiektem. Podziemna trasa turystyczna ma zostać utworzona we współpracy Książa z Państwową Akademią Nauk oraz Muzeum Gross-Rosen z Rogoźnicy. W 2005 r. odnotowano znaczny wzrost w stosunku do 2004 r. - o $31,2 \%$, co może być wynikiem włączenia do trasy zwiedzania podziemnego tunelu z okresu II wojny światowej.

Od 2011 r. liczba zwiedzających obiekt cały czas wzrasta. Przyczyn owego wzrostu można upatrywać w intensywnej promocji obiektu w mediach ogólnopolskich, na krajowych oraz zagranicznych targach turystycznych (głównie w ramach przynależności do Dolnośląskiej Organizacji Turystycznej i tym samym do Europejskiego Szlaku Zamków i Pałaców), a także w sukcesywnym restaurowaniu komnat zamkowych i poszerzaniu ekspozycji muzealnych.

Okres zwiedzania Książa można podzielić na trzy sezony: niski (styczeń, luty, marzec, listopad i grudzień), średni (kwiecień, wrzesień i październik) oraz wysoki (maj, czerwiec, lipiec, sierpień). W lutym liczba turystów nieco wzrasta, co jest spowodowane przyjazdami w czasie ferii zimowych. Liczba odwiedzających we wczesnojesiennym okresie, wzrastająca od 2011 r., wynika przeważnie z przyjazdów zorganizowanych grup szkolnych. Duża liczba zwiedzających w maju wynika z cyklicznej organizacji Festiwalu Kwiatów i Sztuki, przyciągającego do Książa miłośników florystyki. Wyraźny szczyt sezonu występuje w sierpniu, kiedy rośnie liczba wyjazdów w góry (w lipcu turyści chętniej wyjeżdżają nad wodę), a od 2013 r. organizowany jest Dolnośląski Festiwal Tajemnic.

\section{Zakończenie}

Analizując istniejącą ofertę turystyczną zamku Książ, można stwierdzić, iż:

1. Powołana w 1991 r. Spółka koncentruje swoją ofertę przede wszystkim na turystyce kultury wysokiej, tj. dziedzictwa kulturowego, muzealnej oraz eventowej.

2. Zamek kieruje ofertę ku szerokiemu spektrum turystów, poprzez propozycje różnych sposobów zwiedzania (od tras ogólnych, przez fabularyzowane nocne zwiedzanie, po lekcje edukacyjne dla uczniów). 
3. Aplikacja WOW Poland, w której zastosowane zostały beacony (małe nadajniki sygnału radiowego mogące komunikować się ze smartfonami), rewolucjonizujące obecnie rynek turystyczny, została wykorzystana przez zamek Książ jako pierwszy w Polsce.

4. Wystawa „Książ od kuchni” uczyniła Książ najbogatszym w dokumentację fotograficzną zamkiem w Polsce, a zarazem przyciągnie, w ramach turystyki biograficznej, miłośników życia księżnej Daisy von Pless.

5. Kolejną rozwijającą się formą ruchu turystycznego jest turystyka przyrodnicza, zarówno w odniesieniu do 14 tarasów zamkowych, jak i palmiarni.

6. Można domniemywać, iż przez stałe wzbogacanie eksponatów muzealnych oraz otwarcie w 2017 r. podziemnej trasy turystycznej nastąpi wzrost ruchu turystycznego, w tym wzrost liczby zwiedzających zaabsorbowanych turystyką militarną.

7. Jednym z głównych segmentów działalności są również usługi hotelarskie, do których Spółka dostosowuje dodatkowe moduły, m.in. vouchery pobytowe.

8. Od 2012 r. zarządcy Książa skupiają się także na rozwoju turystyki biznesowej poprzez stworzenie i rozwój nowoczesnego centrum kongresowego.

\section{Literatura}

Będkowska-Karmelita A., 2004, Zamek Książ i okolice, Alkazar, Opole.

Kajzer L., Kołodziejski S., Salm J., 2007, Leksykon zamków w Polsce, Arkady, Warszawa.

Klimek S., 2001, Zamek Ksiąz: architektura i historia, VIA-Nowa, Wrocław.

Kruszyński P., 2008, Wojenne tajemnice zamku Książ, Wydawnictwo Rotoryf, Świdnica.

Lejman B., 2015, Metamorfozy zamku Ksiąz, Muzeum Narodowe we Wrocławiu, Wrocław.

Leniartek M.K., 2015, Architektura dla kultury w krajobrazie Wałbrzycha, [w:] Bielawska S. (red.), Nowa Kronika Wałbrzyska, t. III, Fundacja Museion, Wałbrzych.

Łuczyński R.M., 1993, Zamki sudeckie, Dział Wydawnictw Centralnego Ośrodka Informacji Turystycznej, Jelenia Góra.

Łuczyński R.M., 1997, Zamki i pałace Dolnego Śląska, Sudety i Przedgórze Sudeckie, Oficyna Wydawnicza Politechniki Wrocławskiej, Wrocław.

Łuczyński R.M., 2010, Losy rezydencji dolnoślaskich w latach 1945-1991, ATUT, Wrocław.

Rosicka B., 2016, Wpływ nagłośnienia poszukiwań ,złotego pociagu” na ruch turystyczny w Wałbrzychu i okolicach, [w:] Włodarczyk B. (red.), Człowiek w turystyce. Role, potrzeby zachowania. Warsztaty z geografii turyzmu, t. VII, Wydawnictwo Uniwersytetu Łódzkiego, Łódź.

Zamek Książ w Wałbrzychu Sp. z o.o., 2014, Księga jakości systemu zarządzania jakościa wg normy PN-EN ISO 9001:2009, Wałbrzych. 